\title{
Transgenic plants as edible vaccines - reality and future prospects
}

\author{
Nickolay N. Domansky
}

International Institute of Cell Biology

I 48 Acad. Zabolotnoho str., Kyiv, 252143, Ukraine

\begin{abstract}
This review describes the recent progress in the construction of transgenic plants for vaccine producti,n Transgenic plants are an attractive and cost-effective alternative to microbial systems for the production s proteins with pharmaceutical value. Advances in biotechnology are enabling plants to be exploited $f$ expression of candidate vaccine antigens with the goal of using the edible plant organs for economicat delivery of oral vaccines. It has recently been shown that genes encoding antigens of bacterial and vira. patinogens can be expressed in plants in a form in which they retain native inmunogenic propertics. Transgenic potato tubers expressing bacterial antigens stimulated humoral and mucosal immune response, when they were provided as a food. Although the utility of "edible vaccines" to prevent disease remains $t i$ be established, the successful implementation of this strategy can be the first step on the way to modern vaccines of new generation.
\end{abstract}

Introduction. Research on new vaccines has used molecular biology to identify the antigenic determinants of infectious disease agents and to develop genetic engineering approaches to produce and deliver these antigens as subunit vaccines. In recent studies, twols of plant biotechnology have been added to these efforts. It has been found that transgenic plants provide a novel system for production of recombinant proteins that act as oral immunogens when the plant products are consumed as food.

Many infectious agents colonize or invade epithelial membranes; these include bacteria and viruses that are transmitted via contaminated food or water or by sexual contact.

Vaccines that are effective against these infections must stimulate the mucosal immune system to produce secretory $\operatorname{IgA}(\mathrm{S}-\mathrm{IgA})$ at mucosal surfacis such as the gut and respiratory epithelia. In general, a mucosal immune response is more effectively achieved by oral, rather then parenteral, antigen delivery. Several particulate antigens have proven to be effective oral immunogens, including live and killed microorganisms. By comparison with parenteral immunization, oral immunization using subunit or soluble antigens is of ten inefficient at stimulating an immune

(C) N. N. DOMANSKY, 1998 response, and requires larger amounts (mg versus $\mu \mathrm{g}^{\prime}$ of antigen.

Subunit vaccines based upon recombinant cellculture expression systems are feasible but, for commercial-scale production, these systems require fer mentation technology and stringent purification pro tocols so that sufficient amounts of recombinan protein can be obtained for oral delivery. Even witt technological improvements, fermentation-based su bunit vaccine production may be prohibitively ex pensive technology for developing countries where novel oral vaccines are urgently needed. Transgenic plants that express antigens in their edible tiss'd might be possible simply through consumption of a «edible vaccine».

The concept of vaccine production in transgeric plants was introduced about 6 years ago by Charles Arntzen and Hugh Mason at Texas A\&M Universitv [1] greatly stimulating research in this directio: [2-8].

In general, research in this field falls into tort: general categories. First, experiments have been conducted to determine the capacity of plants to produc: foreign proteins that retain antigenic determinants necessary for effective immunization. Second, the oral immunogenicity of plant-derived proteins has beer evaluated with special emphasis on th: 
immunogenicity of food samples. Third, research has been conducted to find an appropriate food crop that could be used for both production and distribution of raccines, with special emphasis on the developing world.

Hepatitis B surface proteins. The first studies of candidate vaccine expression in transgenic plants have been carried out using the gene encoding hepatitis B surface antigen (HBsAg) [1, 3]. This protein was chosen because the conımercially available vaccine cnd the associated human immune response have been very well characterized, because the structure of the immunogenic form of that protein was known, and because the availability of a cost-effective recombinant $H B V$ vaccine is a high priority especially for the developing countries. Morcover, the existence of commercially available test systems for $\mathrm{HBV}$ detection substantially simplified the procedure of $\mathrm{HBsAg}$ detection in plant tissues.

The envelope of hepatitis B virus (HBV) consists of three polypeptides which comprise the large (L), middle (M) and major or small ( $\mathrm{S}$ or $\mathrm{HBs} A g$ ) protein components. These three proteins are encoded in a large open reading frame, which is divided into preS1, rreS2 and the $\mathrm{S}$ gene. The $\mathrm{S}$ protein or $\mathrm{HBsAg}$ is a niajor component of the hepatitis $B$ virions and contains 226 amino acids. The HBV $M$ protein contains additional 55 amino acid residues at the N-terminal of the S protein, usually called the preS2 antigen. Similarly, the L protein contains additional 108-119 amino acids, depending on the serotype of the virion, at the $\mathrm{N}$-terminal of the $\mathrm{M}$ protein [9].

The $S$ gene was introduced into cells of tobacco [1] and potato [3] plants and individual transformants were regenerated. When extracts from transgenic plant tissues were examined the presence of HBsAg were revealed by ELISA using monoclonal antibodies directed against human-serum-derived HBsAg. Further examination of plant-derived $\mathrm{HBsAg}$ purified by immunoaffinity chromatography revealed the presence of spherical virus-like particles with an average size of $22 \mathrm{~nm}$. These particles exhíbited properties that were very similar to the subviral particles obtained from human serum and to the recombinant HBsAg which is formulated in the commercial vaccine produced in yeast cells [1]. Importantly, HBsAg in the particle form was found to be nuch more immunogenic than that in the form of the peptide alone [10].

To evaluate the immunogenicity of plant-derived HBsAg it was used for parenteral immunization of mice. Anti-HBsAg antibodies were recovered which riacted with authentic $\mathrm{HBsAg}$ from human serum. This was the first indication, that antigenic properies of the protein were maintained in transgenic plants Subsequently, $\mathrm{T}$ cells were isolated from mice immunized with plant-derived $\mathrm{HBs} A g$. When grown in culture, these $T$ cells could be activated using con mercial vaccine as well as a synthetic peptide which mimics the «a» epitope determinant of $\mathrm{HBsAg}$. In total, the immunology studies conducted to date show that the recombinant $\mathrm{HBs} A g$ recovered from plant cells retain both $B$ and $T$ cell epitopes [5].

Although recombinant $\mathrm{HBV}$ vaccines have showr that HBsAg alone is sufficient to inusce a highly protective immunity, experiments in animals have highlighted the potential benefits which might resu!t from the inclusion of the preS2 domain in anti-HBV vaccines $[11]$. The preS2 domain is also immunogenic in humans and elicit anti-preS2 responses during natural HBV infection, which often occur prior to $a:$ other anti-HBV response [12]. For this reason, ins? HBV M protein gene (preS2 containing HBsAg) ind: been recently expressed in plants [8] and physical and immunological properties of this protein wcro evaluated [13]. These studies have demonstrated that plant cells have the capacity to not only synthesize $1:$ protein but also to allow it to be assembled in ar. immunologically active form.

To evaluate the immune response to plant-de rived $M$ protein and to compare it to the response is HBsAg from serum (preS2 containing HBsAg), HgV vaccine and plant-derived $\mathrm{HBsAg}$, Balb/c mice wers' immunized intraperitoneally with corresponding antigens. Kinetics of antibody responses were studies a to 14 weeks after primary immunization. The results presented in Fig. 1 indicate that both plant-deriver HBV proteins can elicit the anti-HBsAg antibodies in mice and that the plant-derived $M$ protein is nearly as inmunogenic as the control preS2 containing $\mathrm{HBsAg}$ isolated from serum. Moreover, the presence of anti-preS2 antibodies in the sera of immunized $\mathrm{Balb} / \mathrm{c}$ mice was detected in mice immunized with the preS2 containing proteins (Fig. 2). These results suggest that plant system can provide an alternative method of producing the HBV M protein suitable f.r. vaccination.

Recently, it was also shown that the plant. derived HBV $M$ protein given to mice by oral int:bation (gavage) stimulated serum antibody respons: and corresponding specific antibodies were detecies [14].

Escherichia coli heat-labile enterotoxin B su bunit. The choice of which antigens to use in th initial studies has been strongly influenced by thit desire to determine if transgenic plant materids containing foreign antigens will result in oral immunization and stimulate a mucosal immune respons 


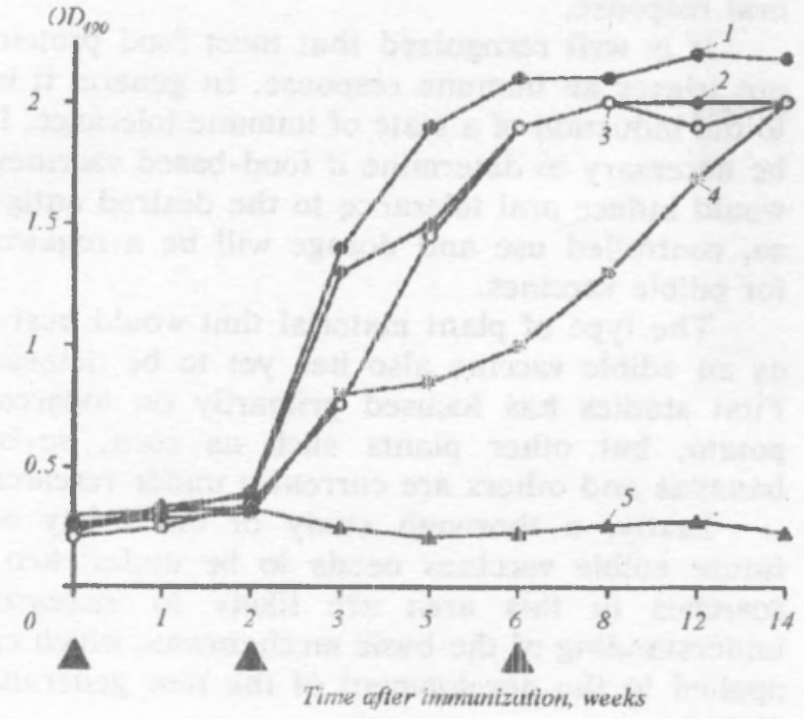

Fig. 1. Kinetics of anti-HBsAg antibody responses in Balb/c mice: 1 - serum HBsAg; $2-\mathrm{M}$ protein; 3 -vaccine; $4-\mathrm{S}$ protein; 5 - negative control. Mice were immunized intraperitoneally with the same amounts of plant-derived $M$ and $S$ protisins, HBsAg from serum and Engerix vaccine. Solid arruivs indicate the time of vaccination $(0,2$ nd and 6 th week). The presence of anti-HBsAg antibody were monitored by ELISA

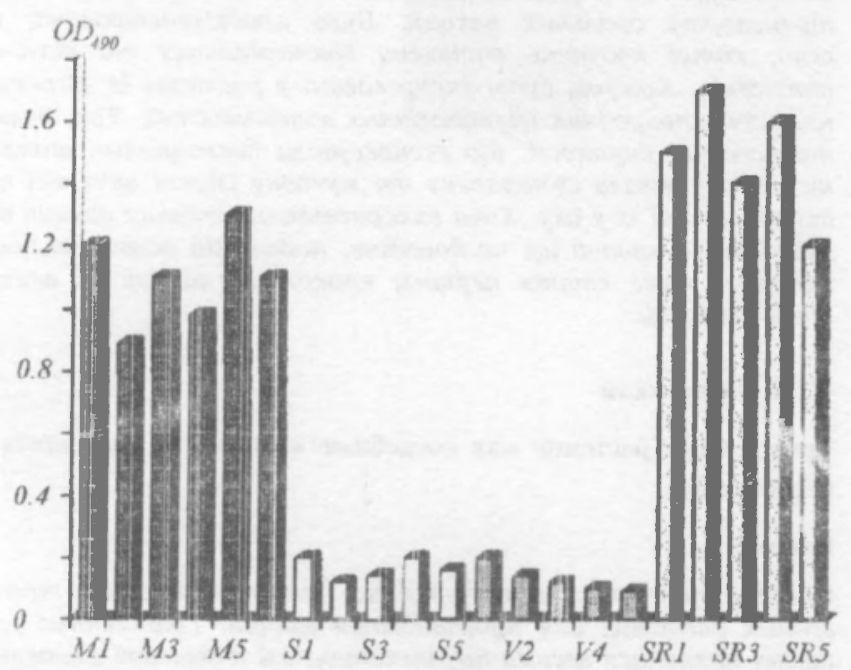

Fig. 2. Comparison of anti-pre $\$ 2$ antibody responses in mice. 12 weeks post-immunization sera from individual mice immunized with plant-derived $M$ protein (M1 - M6), plant-derived S protein (SIS5), Engcrix vaccine (V1-V5) and HBsAg from serum (SR1SR5) wire tested for the presence of anti-preS2 antibody by EIISA
Thus, antigens with the high mucosal immune response have been the early targets for plant-based expression.

The binding subunit of the heat-labile enterotoxin of $E$. coli (LT-B) was an obvious candidate for evaluation in plant expression system since it has been extensively characterized in structural and immunological studies.

The heat-labile enterotoxin (LT) from $E$. coli is a multimeric protein that is structurally, functionally and antigenically very similar to cholerz toxin $(\mathrm{CT})$. It was found that LT has one A subunit (LT-A) and a pentamer of B subunits (LT-B). Specific binding of the nontoxic LT-B pentamer to the $\mathrm{G}_{\mathrm{M}}$ gangliosiaes present on epithelial cell surfaces allows entry of th toxic LT-A subunit into cells [15]. Antibody in terference with binding of the B subuitit to cells, th $w$ : blocking toxin activity, is the basis of attempts to u.e the $B$ subunit as a vaccine component. Because $L T-t$ is very similar in structure and immunological priperties to the CT-B, immunization with CT-B lcaus to cross-protection against enterotoxigenic $E$. coii LT-B and CT-B are both potent strong oral immunogens.

LT-B also has recently been expressed in plan:s although the levels of expression were low $[2 \mid$. Th. oral immunogenicity of recombinant LT-B was teste $c^{\prime}$ in mice and compared with bactcrial LT-B. Whes given orally to mice by gastric intubation, the planiderived antigen stimulated humoral and mucosai immune responses with titers comparable to the bacteria-derived LT-B. In addition, the antibodies produced against the tobacco-derived LT-B were abl to neutralize LT activity, indicating the potentra' protective value of the immune response.

The oral immunogenicity of unpurified recombinant LT-B was also assessed by feeding raw transgenic potato tubers to mice. After only four feedings of $5 \mathrm{~g}$ tuber samples to mice, mucosal and serum antibodies were recovered. No immune response was observed in animals that were fed nontransformed tubers.

It should be also noted that $C T$ and I.T are excellent oral adjuvants, which stimulate immunt responses against co-fed antigens at concentration, well below those that cause diarrhea.

Norwalk virus capsid protein. Further evidence to support the concept of edible vaccines have recently been obtained in experiments with plant-derived $\mathrm{No}$ walk virus capsid protein (NVCP). Norwalk virus is a member of the Caliciviridae family and causes epidemic acute gastroenteritis in humans. As in the case of HBV, expression of NVCP in plant cells yields .. protein that self-assembles in plant cclls into virus 
like particles. The plant-derived NVCP was orally immunogenic in mice. Extracts of tobacco leaf expressing NVCP were given to CDI mice by gavage and the treated mice developed both serum IgG and secretory IgA specific for Norualk virus-like particles. Furthermore, when potato tubers expressing NVCP were fed directly to mice, they developed serum IgA specific for Norwalk virus [7].

Vaccines for animal diseases. Edible vaccines can also provide efficient and humane strategies for disease prevention in production of companion animz.ls, as well as feral populations. It is practically possible to generate vacines against viral and bacterial infections by expressing corresponding antigens in plant tissues edible for animals. The already mentioned LT-B subunit is the most likely candidate for the first commercial vaccine, as enterotoxigenic $E$. coii strains readily infect animals as well. Admittedly, vaccines for animals are a more likely target for edible-vaccine technology in the near future than vaccines for human as the latter need more detailed inspections for safety.

Recently, transgenic plants have been generated that expressed the gene encoding the glycoprotein ( $G$-protein) that coats the outer surface of the rabies virus $[6,14]$.

Although the immunogenicity of these material has yet to be evaluated, it is encouraging to note that bait containing some $G$-protein produced in a more traditional in vitro system was effective in immunizing raccoons orally, providing protection against «street virus» challenge.

Future prospects. The research conducted to date hais demonstrated that transgenic plants have the capacity to synthesize and accumulate subunit antigenic proteins that retain immunological properties of their native counterparts. In the case of $\mathrm{HBV}$ proteins and NVCP, virus-like particles accumulated in plant cells. It is very significant as the particulate form is very important in determining immunogenic properties and has greater oral immunogenicity than soluble proteins.

Studies remaining to be conducted will involve the evaluation of dosage requirements for plantdelivered vaccines. Successful experiments condusted thus far have used proteins (LT-B and NVCP) with very high oral immunogenicity. It will be necessary to determine if other proteins, which may not be normally transmitted orally, will be as effective in inducing an oral response. From this point of view the results of the oral immunization with the plantderived HBV $M$ protein are rather encouraging. Multi-subunit vaccines, including oral adjuvants such as LT or CT (or derivatives thereof), and various fused proteins could be also used for enhancing the oral response.

It is well recognized that most food proteins do not trigger an immune response. In general it is due to the induction of a state of immune tolerance. It will be necessary to determine if food-based vaccines also would induce oral tolerance to the desired antigen If so, controlled use and dosage will be a requiremunt for edible vaccines.

The type of plant material that would best sirve as an edible vaccine also has yet to be determiaed First studies has focused primarily on tobacco and potato, but other plants such as corn, soyocan. bananas and others are currently under research.

Lastly, a thorough study of the safety o: the future edible vaccines needs to be under'cken. $\{e$ searches in this area are likely to increase out understanding of the basic mechanisms, which can be: applied to the development of the new generation o. vaccines.

\section{M. М. Доманський}

Трансгенні рослини як істівні вакцини - реальність та перспективи

Резюме

Огляд суцасних літературних даних про створення трснсеен них рослин для виробництва вакцин. Трансгенні рослини є дуж привабливою та дешевою альтернат.євою існуючім мікро біологічним системам виробнищтва білків о.и фармацевтіки. Успіхи сучасної біотехнологї̈ відкрили можливість ехспресую ти у рослинах різні антигени, цо викоғистювуються скя вакцинацї, з метою використання їстівних иастин рослин для транспорту оральних вакцин. Було продемонстрозано, ицо гени, котрі кодують антигени бактеріальних та вірусни, патогенів, мохуть бути експресовані у рослинах із зогреженням їхніх природних імунологічних властивостей Так, бульки трансгенної картоплі, що експресували бактеріальні антигі ни, стимулювали гуморальну та мукозну імукні оідповіді пви використанні їх у іху. Хоча використання їтівних вакцин для запобігання хвороб ще не доведене, подальщій розвиток иього напряму мохе стати периим кроком ио идяху до вскцин нової генерації.

\section{H. Н. Доманский}

Трансгенные растения как съедобные вакцичы - реилыность $v$ : перспективы

Резюме

Обзор современных литературных данньіх о созданим тра сс генных растений для производства вакцин трансеен:tb!е р тения яоляются весьма привлекательной и дешевой альмсрни тивой существующим микробиологическим системам производства белков для фармацевтики. Успехи современной биотехнологии открыли возможность экспрессировать в расппниях разлинные антигены, используемые при вакцинации, для применения съедобных частей растений при транспорте оральньіх вакцин. Было продемонстрировано, что гень!, кодирукцие антигены бактериальных и вирусных патогенов, мосую. 
бbimь экспрессированы в растениях с сохранением их природных иммунологических свойсти. Так, кіубни трансгенного кактофеля, әкспрессировавице бактериальные антисень, стиму.лировали гуморальный и мукозный имжунные ответы при упстреблении их в пицу. Хотя использование съедсбных вакцин для предоторащения болезней еще не доказано, дальнейщее развитие атого направления мохет стать первым шагом на пугии к созданию вакцин нового поколения.

\section{REFERENCES}

I. Mason H. S., Lam D. M.-K., Arntzen C. J. Expression of hepatitis B surface aritigen in transgenic plants // Proc. Nat. Acad. Sci. USA - 1992.-89.-P. 11745-11749.

2. Haq T. A., Mason H. S., Clements J. D., Arntzen C. J. Oral immunization with a recombinant bacterial antigen produced in transgenic plants // Science.-1995. -268.-P. 714-715.

3. Dormansky N. N., Ehsani P., Salmanian A-H., Medvedeva T. Organ-specific expression of hepatitis $B$ surface antigen in potaro // Bioteckinol. Lett.-1 995. - 1 7.-.-P. 863-866.

4. Mason H. S., Arntzen C. $\%$. Transgenic plants as vaccine production systems // Trends Biotechnol.-1995.-13.P. 388-392.

5. Thanavala $Y$., Yang $Y .-F$., Lyons $P$. et al. Immunogenicity of transgenic plant-derived hepatitis B surface antigen // Proc. Nat. Acad. Sci. USA.-1995.-92.-P. 3358-2261.

5. McGarvey P. B., Hammond J., Dienelt et al. Expression of the rabies virus glycoprotein in transgenic tomatoes // Bio/Technology. -1995.-13.-P. 1484-1487.

7. Mason H. S., Ball J. M., Shi J-J. et al. Expression of Norwalk virus capsid protein in transgenic tobacco and potato and its oral immunogenicity in mice // Proc. Nat. Acad. Sci. USA 1996. - 93. -P. 5335-5340.

8. Ehsani P., Khabiri A., Domansky N. N. Polypeptides of hepatitis B surface antigen produced in transgenic potato // Gene.-1997.-190.-P. 107-111.

9. Tiollais P., Pourcel C., Dejean S. The hepatitis B virus // Nature. $-1985 .-317 .-P .489-495$.

10. Cabral G. A., Marciano-Cabral F., Funk G. R. et al. Cellular and humoral immunity in guinea pigs to two major polypeptides derived from hepatitis B surface antigen // J. Gen. Virol.1978. -38.-P. 339-350.

11. Millich D. R., Thornton G. B., Neurath et al. Enhanced immunogenicity of the pre-S region of hepa:tis $B$ surface antigen // Science.-1985.-228.-P. 1195-1198.

12. Petre J., Rutgers T., Hauser P. Properties of arecombinant yeast-derived hepatitis $B$ surface antigen containing $S$, pre $S Z$ and preSl antigenic domains // Arch. Virol. (Suppl.).1992.-24.-P. 137-141.

13. Khabiri A., Ehsani P., Domansky N. Characterization of the hepatitis B middle (M) surface protein synthesizea in trans genic potato plants // Manuscript submitted.

14. Domansky N., Khabiri A., Ehsani P. et al. Enhanced immurio genicity of transgenic plant-derived hepatitis B middle surface antigen // 5th Int. Congr. of Plant Mol. Biol. (Singapore, $21-27^{\text {th }}$ September 1997).-P. 1257.

15. Sixma T. K., Pronk S. E., Kalk K. H. et al. Crystal structure of a cholera toxin-related heatlabile enterotoxin from $E$. coli /, Nature. -1991._351._P. 371-377.

Received 26.01.93 